\title{
The biological effects of diagnostic cardiac imaging on chronically exposed physicians: the importance of being non-ionizing Maria Grazia Andreassi*
}

\author{
Address: Laboratory of Cellular Biology and Genetics, CNR Institute of Clinical Physiology, Pisa, Italy \\ Email: Maria Grazia Andreassi* - andreas@ifc.cnr.it \\ * Corresponding author
}

Published: 22 November 2004

Cardiovascular Ultrasound 2004, 2:25 doi:10.1/86/1476-7/20-2-25
Received: 09 November 2004

Accepted: 22 November 2004

This article is available from: http://www.cardiovascularultrasound.com/content/2/I/25

(C) 2004 Andreassi; licensee BioMed Central Ltd.

This is an Open Access article distributed under the terms of the Creative Commons Attribution License (http://creativecommons.org/licenses/by/2.0), which permits unrestricted use, distribution, and reproduction in any medium, provided the original work is properly cited.

\begin{abstract}
Ultrasounds and ionizing radiation are extensively used for diagnostic applications in the cardiology clinical practice. This paper reviewed the available information on occupational risk of the cardiologists who perform, every day, cardiac imaging procedures. At the moment, there are no consistent evidence that exposure to medical ultrasound is capable of inducing genetic effects, and representing a serious health hazard for clinical staff. In contrast, exposure to ionizing radiation may result in adverse health effect on clinical cardiologists. Although the current risk estimates are clouded by approximations and extrapolations, most data from cytogenetic studies have reported a detrimental effect on somatic DNA of professionally exposed personnel to chronic low doses of ionizing radiation. Since interventional cardiologists and electro-physiologists have the highest radiation exposure among health professionals, a major awareness is crucial for improving occupational protection. Furthermore, the use of a biological dosimeter could be a reliable tool for the risk quantification on an individual basis.
\end{abstract}

\section{Introduction}

Over the last 30 years, medical cardiology imaging has rapidly grown, becoming an essential part of the cardiology clinical practice. Imaging procedures include conventional imaging tests such as echocardiography, radionuclide imaging, and angiography as well as a newer imaging techniques such as emission computed tomography and magnetic resonance imaging which promise to expand diagnostic capabilities [1]. These techniques widely differ not only for what concerns costs, availability and technical information, but they also differ in environmental and health hazards.

Many cardiac procedures can deliver high radiation doses to the clinical staff [2]. This exposure may represent a significant health risk, resulting in deleterious clinical impli- cations which can affect not only the personnel involved, but also their progeny [3-5]. Unfortunately, many physicians are unfamiliar with radiation biology or the quantitative nature of the risks and, frequently, ultrasound and ionizing radiation risks are misunderstood [6-9]. The purpose of this paper is to discuss the published evidence on health effects of cardiac imaging procedures employing ultrasound and ionizing radiation.

\section{Ultrasound imaging}

Ultrasound imaging, also called sonography, is a method of obtaining human body images through the use of high frequency sound waves. Ultrasounds are mechanical vibrations with frequencies above the human limit of audibility. The use of ultrasounds in order to obtain images for medical diagnostic purposes, typically employs 


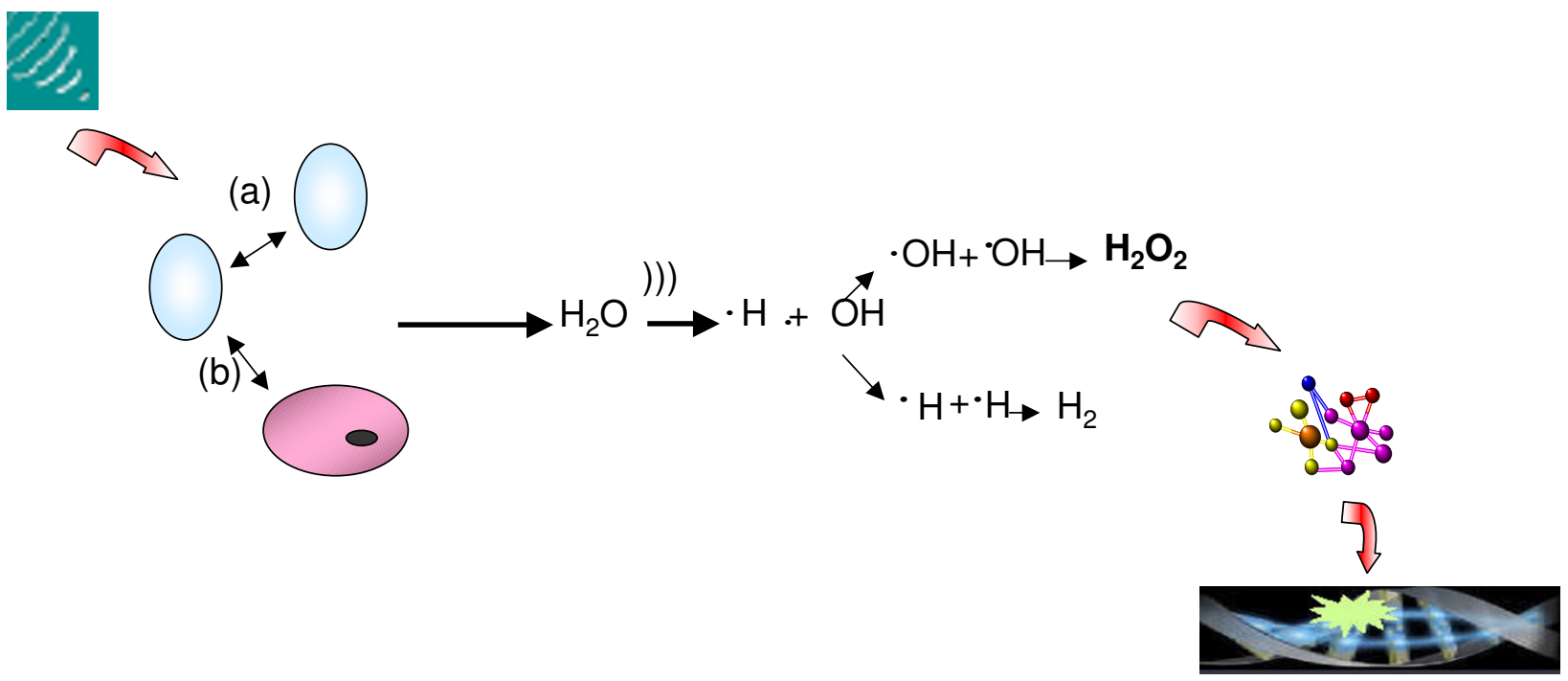

DNA DAMAGE ?

\section{Figure I}

At high acoustic pressure, ultrasound is capable of causing rapid bubble which grow and collapse among them (a) and cells (b). This mechanism results in the production of sufficient energy to disrupt chemical bonds and produce reactive free radicals, that may interfere with DNA.

frequencies ranging from $2 \mathrm{MHz}$ to about $12 \mathrm{MHz}$ [10]. Ultrasound does not use ionizing radiation, and it is the preferred image modality for monitoring both pregnant women and their embryos or fetus [10]. In contrast to ionizing radiation, which can damage biological materials by dislodging electrons from atoms and molecules, ultrasounds do not cause ionisation. They usually interact with human tissue primarily by generating heat, but also nonthermal effects which are ascribed to cavitation (i.e. micro-bubble) [11]. The process of cavitation includes ultrasounds mechanical effects which lead to hydrodynamic breaks of hydrogen bonds and oscillation of hydrogen ions, and chemical effects produced by the occurrence of free radicals in intercarionic space in the process of cavitation (Figure 1). Theoretically, these free radicals may interfere with DNA, causing chromosomal damage. Indeed, ultrasounds of diagnostic intensities induced detectable DNA damage in animal cells [12,13]. Currently, there is a body of studies on human DNA damage from exposure to therapeutic and diagnostic ultrasounds [14-20]. In particular, Stella et al. [15] reported that therapeutic ultrasound induce a significant increase in sister chromatid exchanges (SCEs) in human lymphocytes after treatment both in vitro and in vivo. In the same study, no increase in chromosomal aberrations was observed during and after ultrasound therapy [15]. Subsequently, some reports on human cells indicated that ultrasound was not able to induce SCEs or chromosomal damage (Table 1). Thus, there is at present no indication that exposure to medical ultrasound is capable of inducing genetic effects 
Table I: Summary of studies on genetic effects of medical ultrasounds

\begin{tabular}{|c|c|c|c|c|}
\hline Author, Year (Ref) & Assay System & Endpoint & Exposure & Result \\
\hline Miller et al., 1983 (14) & $\begin{array}{l}\text { Human lymphocytes exposed in } \\
\text { vitro }\end{array}$ & SCE & $\begin{array}{l}2 \mathrm{MHz} \\
\text { SPPA intensity } 100 \mathrm{~W} / \mathrm{cm}^{2}\end{array}$ & Negative \\
\hline Stella et al., 1984 (15) & $\begin{array}{l}\text { Human lymphocytes exposed in } \\
\text { vitro }\end{array}$ & $\begin{array}{l}\text { SCE } \\
\text { CA }\end{array}$ & $\mathrm{I} \mathrm{W} / \mathrm{cm} 2 ; 0.860 \mathrm{MHz}$; for $40-160 \mathrm{sec}$ & Positive/ Negative \\
\hline Barnett et al., 1987 (16) & $\begin{array}{l}\text { Human lymphocytes exposed in } \\
\text { vitro }\end{array}$ & SCE & $\begin{array}{l}\text { 3.I } \mathrm{MHz} \\
\text { SPPA intensities from } 15 \text { to } 135 \mathrm{~W} / \\
\mathrm{cm}^{2} \text {. }\end{array}$ & Negative \\
\hline Carrera P et al., I 990 (I7) & $\begin{array}{l}\text { Chorionic villi exposed in vitro } \\
\text { Chorionic villi from exposed } \\
\text { pregnant women }\end{array}$ & SCE & $\begin{array}{l}2 \mathrm{MHz} \text { at I, } 2,3 \mathrm{~h} \\
\text { Diagnostic US for } 20 \mathrm{~min} \text { (in vivo } \\
\text { exposure }\end{array}$ & Negative \\
\hline Miller et al., 1991 (18) & $\begin{array}{l}\text { Human lymphocytes from } \\
\text { exposed patients }\end{array}$ & SCE & $\begin{array}{l}4 \text { patients underwent therapeutic US } \\
4 \text { healthy persons underwent sham- } \\
\text { therapeutic US }\end{array}$ & Negative \\
\hline Martini et al., I991 (19) & $\begin{array}{l}\text { Lymphocyte and lymphoblastoid } \\
\text { cells exposed in vitro }\end{array}$ & SCE & $\begin{array}{l}5 \mathrm{MHz} \text { for } 20 \mathrm{sec} \text {, I min, } 5 \mathrm{~min} \text {, and } \\
20 \mathrm{~min}\end{array}$ & Negative \\
\hline Sahin O et al., 2004 (20) & $\begin{array}{l}\text { Human lymphocytes from } \\
\text { exposed patients }\end{array}$ & $\mathrm{MN}$ & $\begin{array}{l}10 \text { patients underwent } 10 \text { session of } \\
\text { US therapy at I } \mathrm{MHz} \text { for } 10 \mathrm{~min} \text { and } \\
10 \text { control subjects underwent sham- } \\
\text { therapeutic US }\end{array}$ & Negative \\
\hline Garaj-Vrhovac and Kopjar, 2000 (22) & $\begin{array}{l}\text { Human lymphocytes from } \\
\text { cardiologists working with } \\
\text { Doppler ultrasound }\end{array}$ & $\begin{array}{l}\text { CA } \\
\text { SCE } \\
\text { MN }\end{array}$ & $\begin{array}{l}\text { Unit working with colour Doppler US } \\
\text { (transducer frequencies } 2.5-7.5 \mathrm{MHz} \text {. } \\
\text { SPPA intensity } 60-110 \mathrm{~W} / \mathrm{cm}^{2} \text {. }\end{array}$ & Positive \\
\hline
\end{tabular}

SCE: sister-chromatid exchange; MN: Micronuclei; CA: Chromosomal aberrations; SPPA: Spatial Peak Pulse Average

and representing a serious health hazard for clinical staff. However, very little information is available on the genetic effects of individuals occupationally exposed to chronic ultrasound. Medical staff can be exposed to handtransmitted ultrasound waves in the work-place.

Indeed, ultrasound sources do not transmit acoustic energy into air, and only low level ultrasound reaches medical personnel through handling of the probe [21]. Probably, occupational exposure to ultrasound occurs during training procedures [21]. In fact, medical personnel often apply diagnostic ultrasound to themselves during training or during technique demonstrations [21]. Consequently, ultrasound is not harmful like the other types and sources of radiation. However, a recent investigation indicated that medical personnel from a cardiology unit working with colour Doppler ultrasonic equipment had an increased genotoxic damage compared to the control subjects [22]. Therefore, this observation requires further studies in order to determine if chronic exposure to ultrasound might induce genotoxic effects.

\section{lonizing radiation}

Ionizing radiation is known to cause harm. High radiation doses tend to kill cells, while low doses tend to damage or alter the genetic code (DNA) of irradiated cells. The biological effects of ionizing radiation are divided into two categories: deterministic and stochastic effects. Deterministic effects, such as erythema or cataract, have a thresh- old dose below which the biological response is not observed [23-25]. Some interventional procedures with long screening times and multiple image acquisition (e.g. percutaneous coronary intervention, radio-frequency ablation, etc) may give rise to deterministic effects in both staff and patients $[26,27]$.

A stochastic effect is a probabilistic event and there is no known threshold dose. The likelihood of inducing the effect, but not the severity, increases in relation to dose and may differ among individuals.

In fact, the effect of low doses of radiation -less than 50 $\mathrm{mSv}$ - do not cause an immediate problem to any body organ, but spread out over long periods of time after exposure. The biological effects are at DNA level and they may not be detected [23-25]. The cell has repair mechanisms against damage induced by radiation as well as by chemical carcinogens. Consequently, biological effects of low dose radiation on living cells may result in three outcomes: (1) injured or damaged cells repair themselves, resulting in no residual damage; (2) cells die; or (3) cells incorrectly repair themselves resulting in a biological change (Figure 2). Such biological changes include the development of cancer and genetic defects in the future children of exposed parents. At present, however, the effects of low-level exposure remain uncertain [28]. The associations between radiation exposure and the development of cancer are mostly based on populations exposed 


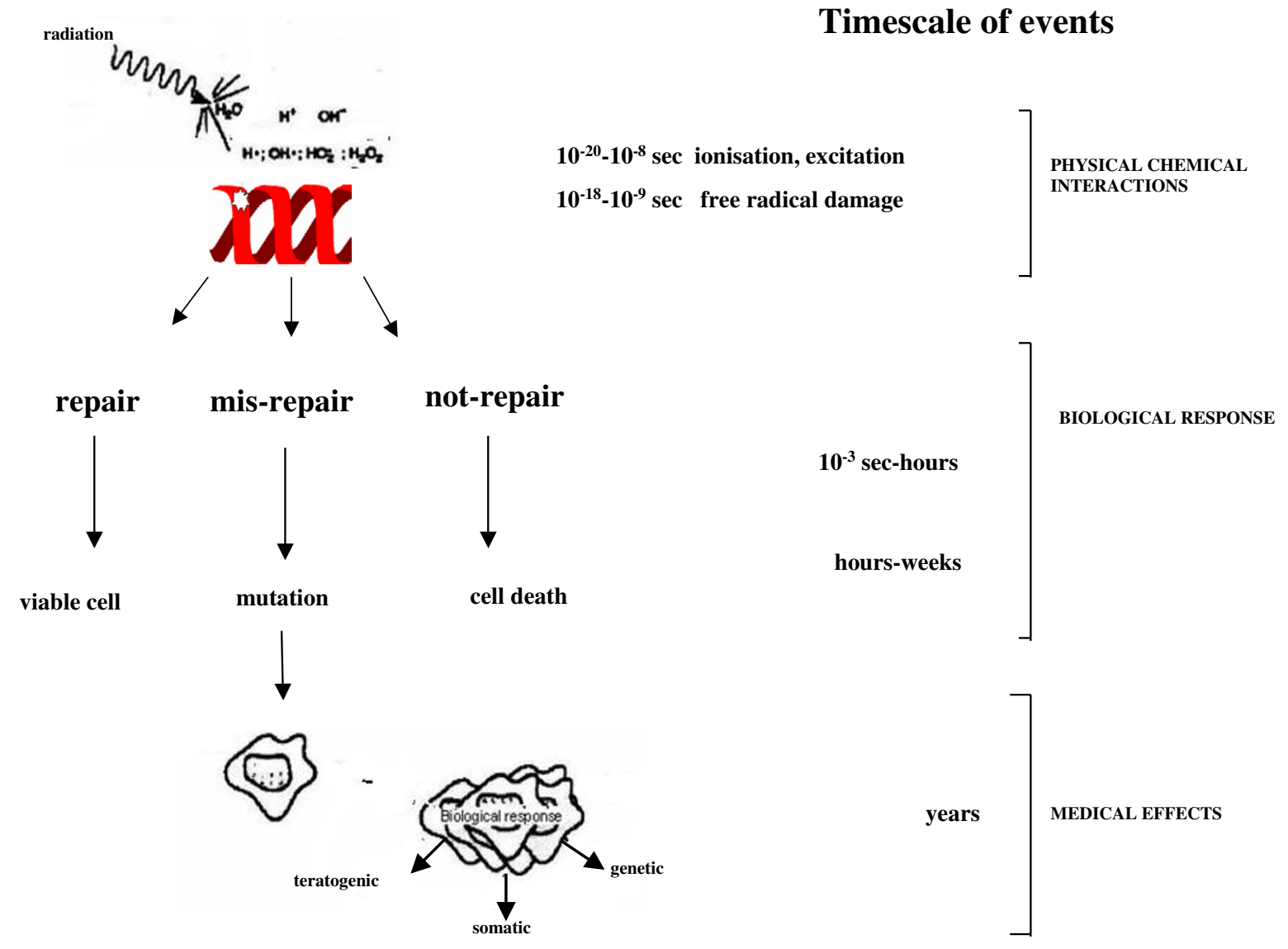

\section{Figure 2}

Radiation damage of DNA. Damaged DNA is screened through the process of DNA repair and mismatch correction. DNA lesions that escape repair, has the ability to produce mutations, which lead to the development and the progression of both cancer and human diseases even decades after exposure.

to relatively high levels of ionizing radiation (e.g., Japanese atomic bomb survivors). Since extraordinary large studies are required to quantify the risks of very low doses of radiation, it is unlikely that we will be able to precisely quantify cancer risk in human populations at doses below $10 \mathrm{mSv}$ [28]. For instance, an epidemiological study of more than 5 million people would be needed to quantify the effect for a $10-\mathrm{mSv}$ dose or less [28]. Our inability to quantify risk does not, however, imply that this risk is negligible. Furthermore, the small (and often not so small) individual risk applied to a large number of individuals, and by protracted exposures, translates into a significant public health problem). As such, the international scientific community has adopted a prudent approach and acknowledged the fact that any level of exposure could potentially lead to biological effects. A linear, no-threshold dose response relationship is used by the IRCP in order to describe the relationship between radiation dose and the occurrence of cancer [29]. This dose-response model suggests that any increase in dose, no matter how small, results in an incremental increase in risk.

Genetic effects are the result of a mutation produced in the reproductive cells of an exposed individual that are passed on to their offspring. These effects may show up as birth defects or other conditions in the future children of the exposed individual and succeeding generation. Indeed, studies with laboratory animals have provided a large body of data on radiation-induced genetic effects [30]. Recently, these effects have been also observed in 
Table 2: Recommended occupational dose limits by International Commission on Radiological Protection (ICRP).

\begin{tabular}{ccc}
\hline TISSUE INJURY & \multicolumn{1}{c}{ OCCUPATIONAL DOSE LIMITS/YEAR } \\
\hline whole body & $20 \mathrm{mSv}$ & $2 \mathrm{rem}$ \\
\hline Lens of the eye & $150 \mathrm{mSv}$ & $15 \mathrm{rem}$ \\
\hline Skin, hands, feet, and other organs & $500 \mathrm{mSv}$ & $50 \mathrm{rem}$ \\
\hline
\end{tabular}

studies of people exposed to radiation from Chernobyl disaster, radiation workers and medical radiologists who have received doses of radiation [31-33]. However, no conclusive evidence exists yet [34,35].

\section{Radiation exposure to cardiologists}

The use of radiation in medicine is the largest source of man-made radiation exposure. According to the latest estimation of the United Nations, an average of $2.4 \mathrm{mSv} /$ year comes from natural sources [24]. In western countries, the exposure dose from medical radiation corresponds to 50 to $100 \%$ of the total natural radiation. In 1997, the German Federal Office for Radiation Protection reported 136 million $\mathrm{x}$ ray examinations and 4 million nuclear medicine diagnostic tests, resulting in a mean effective dose of $2.15 \mathrm{mSv}$ per person per year [36]. Cardiac and interventional procedures account for a large percentage of nuclear and radiological examinations [36]. Of all radiological examinations, $28 \%$ are arteriographies and interventions. An additional $2 \%$ derive from chest Xrays and $37 \%$ from CT: many of them are cardiological referrals. Regarding nuclear medicine, $22 \%$ are cardiological scan. These percentages are likely higher now, since the use of cardiac and interventional procedures is increasing.

Cardiac ionizing procedures expose both patients and medical staff to the highest radiation levels in diagnostic radiology, and recently, as the number of diagnostic and interventional cardiac catheterisation procedures has greatly increased, serious radiation induced skin injuries and an excess of cataract development have been reported in exposed staff [37-39]. Furthermore, it has been suggested that fluoroscopic procedures may be a health hazard and increase the risk for brain tumours in interventional cardiologists [40].

Today, interventional cardiologists represent, indeed, the most important group of exposed among professionally exposed physicians [41,42].
As known, the limit on effective dose for exposed workers should be $100 \mathrm{mSv}$ in a consecutive five year period, subject to a maximum effective dose of $50 \mathrm{mSv}$ in any single year. Radiation dose limits to adult occupational workers provided by the International Commission on Radiological Protection (ICRP) are shown in table 2.

As a matter of fact, the head dose sustained by cardiologists may reach $60 \mathrm{mSv}$ per year, and may in some cases exceed the occupational limit of $150 \mathrm{mSv}$ per year recommended for the lens of the eye [41].

However, the correlation between occupational doses and staff radiological risks is not simple, and it is very dependent on equipment, the specialist, and protocols followed throughout the procedure [43]. Many factors can influence occupational doses for the same radiation dose imparted during cardiac procedure. One of the most important factors is that protection tools are available in catheterisation laboratories and are appropriately used [43]. In addition, another likely reason is a lack of knowledge, information and training in radiation protection [43].

Importantly, a recent survey showed that that most of cardiologists do not correctly evaluate the dose exposure, the medico-legal regulation, the environmental impact and individual bio-risks of the radiological investigations [9]. As shown in table 3, this surprising lack of knowledge of both dose and clinical risk of commonly performed ionising test examinations, is not at all restricted to cardiologists, and seems to be democratically spread across all specialties - from surgeons to orthopaedics, to paediatricians [6-9].

Probably, this unawareness has its root in the difficult perception of a long-term risk associated to radiation exposure. In particular, the perception of cancer risk, which can have a latency period of many years after exposure, is often elusive. Furthermore, the exact risk at very low doses to a specific individual is further complicated by many 
Table 3: Doctors' knowledge of radiation dose and risk for medical ionising testing

\begin{tabular}{|c|c|c|c|}
\hline Author, year (Ref) & Physicians & $\begin{array}{c}\text { Radiological Awareness } \\
\text { Evaluation }\end{array}$ & Results \\
\hline Shiralkar S et al., 2003 (6) & British physicians & $\begin{array}{l}\text { Radiation doses for common } \\
\text { radiological investigations. }\end{array}$ & $\begin{array}{l}97 \% \text { of doctors underestimates dose. } \\
5 \% \text { believes that US use ionising } \\
\text { radiation. } \\
8 \% \text { believes thatMRI use ionising } \\
\text { radiation. }\end{array}$ \\
\hline Finestone A et al., 2003 (7) & Istraeli orthopaedists & $\begin{array}{l}\text { Mortality risk of radiation-induced } \\
\text { carcinoma from bone scan } \\
\text { scintigraphy }\end{array}$ & $\begin{array}{l}\text { Mortality risk was identified correctly } \\
\text { by less than } 5 \% \text { of respondents. }\end{array}$ \\
\hline Lee $\mathrm{Cl}$ et al., 2004 (8) & $\begin{array}{l}\text { Emergency department (ED), } \\
\text { physicians and radiologists }\end{array}$ & $\begin{array}{l}\text { Radiation dose and possible risks } \\
\text { associated with CT scan }\end{array}$ & $\begin{array}{l}\text { Almost all doctors were unable to } \\
\text { accurately estimate the dose. } \\
\text { Only } 9 \% \text { ED physicians believed that } \\
\text { there was increased risk. }\end{array}$ \\
\hline Correia MJ et al., 2005 (9) & Adult and paediatric cardiologists & $\begin{array}{l}\text { Environmental impact, individual bio- } \\
\text { risks, dose exposure and medico-legal } \\
\text { regulation of medical ionising testing }\end{array}$ & $\begin{array}{l}\text { Only } 11 \%, 5 \%, 29 \% \text { and } 42 \% \text { of } \\
\text { physicians correctly identified } \\
\text { environmental impact, individual bio- } \\
\text { risks, dose exposure and legal } \\
\text { regulation, respectively. }\end{array}$ \\
\hline
\end{tabular}

$\mathrm{CT}$ = computed tomography; $\mathrm{MRI}=$ magnetic resonance imaging; $\mathrm{US}=$ ultrasound

factors, such as carcinogenic agents in our environment, cigarette smoke, diet and genetic background.

However, a recent study has estimated that from $0.6 \%$ to $3 \%$ of all cancers are due to medical X-rays [44]. These figures are impressive but may largely underestimate the true risk, since they are referred to radiological data concerning the 1991-1996. Taking into account current radiological activities, medical radiation is likely to account for at least $20 \%$ of cancer in developed countries [45].

With regard to occupational exposure for radiologists and radiotherapists, available epidemiological studies have been recently reviewed by Yoshinaga et al [46]. An excess risk of leukaemia associated with occupational radiation was found among early workers employed before 1950, when radiation exposures were high. In addition, several studies provided evidence of a radiation effect for breast and skin cancer. To date, there is no clear evidence of an increased cancer risk in medical radiation workers exposed to current levels of radiation doses. However, given a relatively short period of time for which the most recent workers have been followed up and in view of the increasing uses of radiation in modern medical practices, it is important to continue to monitor the health status of medical radiation workers [46].

To the fatal cancer risk, one must add the risk of non-fatal cancer and major genetic damage transmitted to the off- spring. It is relevant to underline that the long-term damage may not include only cancer but also other major degenerative diseases, including atherosclerosis $[47,48]$. However, it is important to realize that many difficulties are involved in designing epidemiological studies that can accurately measure the increases in health effects due to low exposures to radiation as compared to the normal rate of cancer. Studies with very large sample size are required in order to quantify the risks of very low doses of radiation. An alternative strategy could be based on the measure of biological effects by using biomarkers as predictors of delayed health outcomes [49].

\section{Biomarkers in the assessment of radiation exposure}

Damage to deoxyribonucleic acid (DNA), which carries the genetic information in chromosomes in the cell nucleus, is considered to be the main initiating event by which radiation damage to cells results in the development of cancer and hereditary disease. Four biomarkers (Figure 3) -analysis of structural chromosome aberrations, micronucleus assay, sister chromatid exchange analysis and comet assay- in peripheral lymphocytes are currently employed in order to study human exposure to environmental carcinogens [50]. Among these, the test of chromosomal aberrations in peripheral blood lymphocytes has the most abundant literature validating that a high frequency of chromosomal breakage is a strong predictor of cancer risk in healthy subjects $[51,52]$. 
a)
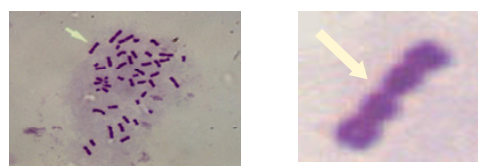

Metaphase with dicentric chromosome

b)

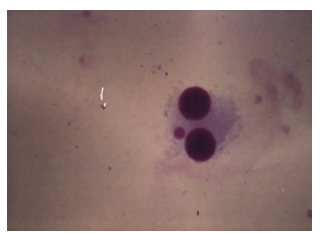

Binucleated cells with MN

c)

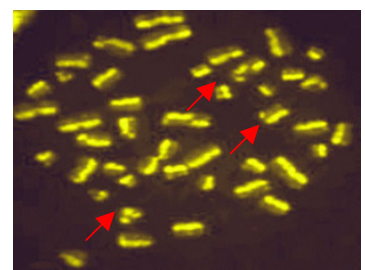

Metaphase with SCEs

d)

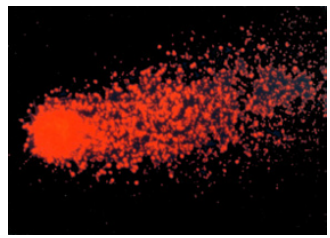

Lymphocyte with comet
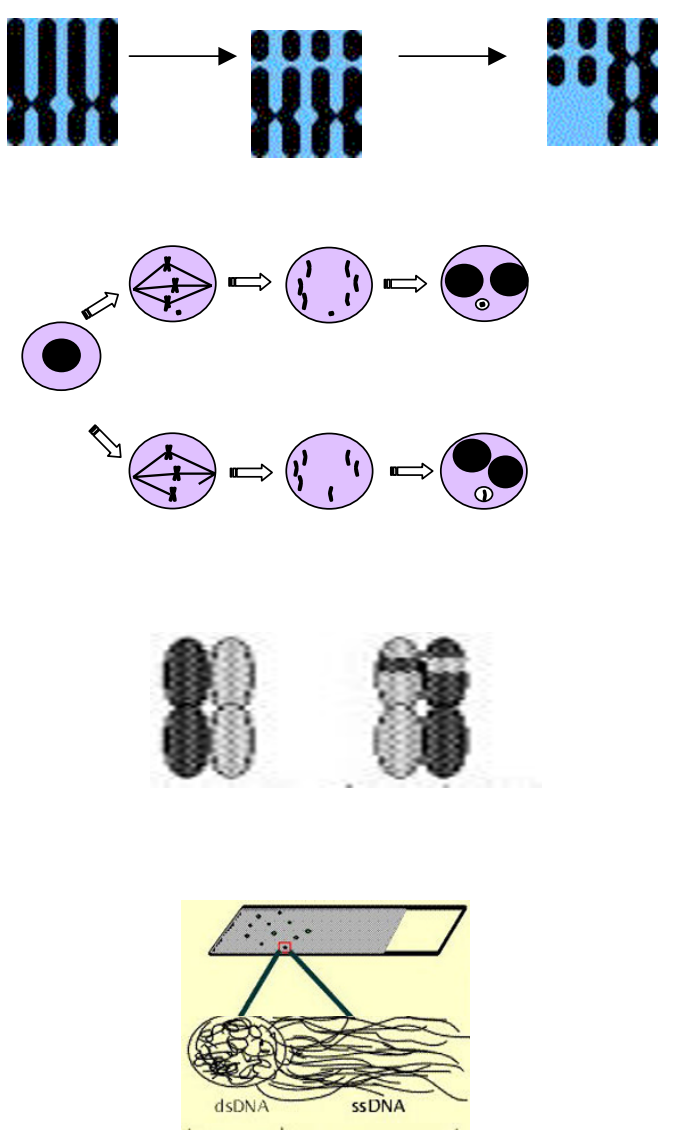

Figure 3

Biomarkers of DNA damage in human lymphocytes: a) Structural chromosomal aberrations (CA) are typical of cancer cells, probably as a manifestation of genetic instability. b) Micronuclei (MN) can originate from chromosome breaks or whole chromosomes that fail to engage with the mitotic spindle when the cell divides. Therefore, the micronucleus test can be considered just as a real "biological dosimeter" for evaluating both numerical and structural chromosome aberrations. c) Sister chromatid exchanges (SCEs) represent symmetrical exchanges between sister chromatids; generally they do not result in chromosomal alterations of the genetic information. c) The Comet assay is an especially sensitive method for detecting DNA single-strand breaks and oxidative DNA damage in individual cells. The entity of the DNA damage is proportional to the length of the comet.

During the last years, the micronucleus assay has become popular since it is fast and inexpensive, and it is considered to be a "biological dosimeter" for exposure to ionizing radiation [53].

The importance of cytogenetic study of peripheral lymphocytes in subjects exposed to ionizing radiation has been reported for more than 20 years, especially in radiol- ogists [54-68]. The available evidence suggests that chronic exposure to low dose radiation has a genotoxic effect on somatic DNA of professionally exposed workers (Table 4). This effect seems to be cumulative over time, although the majority of these studies failed to establish a dose-effect relationship for low doses. The absence of increase of somatic DNA damage in relation to the dose might be explained by various factors. Dosimetry records 
Table 4: Cytogenetic studies in hospital workers

\begin{tabular}{|c|c|c|c|c|c|c|}
\hline Author, year (ref) & Exposed Subjects, $n$ & $\begin{array}{l}\text { Non-exposed } \\
\text { Subjects, } n\end{array}$ & Endpoint & Results & Exposure & $\begin{array}{l}\text { Correlation with } \\
\text { dose (Yes/No) }\end{array}$ \\
\hline Bigatti et al, I988, (54) & $\begin{array}{l}63 \text { (physicians, nurses } \\
\text { and technicians) }\end{array}$ & $\begin{array}{l}30 \text { (ward nurses } \\
\text { and office } \\
\text { personnel) }\end{array}$ & CA & Positive & $<$ legal limit. & No \\
\hline $\begin{array}{l}\text { Barquinero et al, 1993, } \\
\text { (55) }\end{array}$ & 26 (hospital workers) & $\begin{array}{l}10 \text { (healthy } \\
\text { individuals) }\end{array}$ & CA & Positive & $1.6-42.71 \mathrm{mSv}$ & No \\
\hline $\begin{array}{l}\text { Paz-y-Mino et al, } 1995 \text {, } \\
\text { (56) }\end{array}$ & 10 (hospital workers) & $\begin{array}{l}10 \text { (healthy } \\
\text { individuals) }\end{array}$ & $\mathrm{CA}$ & Positive & $\mathrm{I} .84$ mSv/year. & No \\
\hline Vera et al, 1997, (57) & $\begin{array}{l}20 \text { (medical staff } \\
\text { working at an X-ray } \\
\text { department) }\end{array}$ & $\begin{array}{l}20 \text { (general } \\
\text { population) }\end{array}$ & $\begin{array}{l}\text { CA } \\
M N\end{array}$ & Positive & $<25$ mSv/year. & $\begin{array}{l}\text { No (Major DNA } \\
\text { damage in subjects } \\
\text { exposed to both } \\
\text { ultrasound and X-ray) }\end{array}$ \\
\hline Bonassi et al., 1997, (58) & $\begin{array}{l}87 \text { I (hospital workers } \\
\text { from } 4 \text { laboratories) }\end{array}$ & $\begin{array}{l}617 \text { (healthy } \\
\text { individuals) }\end{array}$ & CA & Positive & $\begin{array}{l}\text { Available only } \\
\text { partially and } \\
\text { variable. }\end{array}$ & Yes/No \\
\hline Rozgaj et al, 1999, (59) & $\begin{array}{l}483 \text { (radiologists, } \\
\text { pneumologists, } \\
\text { technicians) }\end{array}$ & $\begin{array}{l}160 \text { (healthy } \\
\text { individuals) }\end{array}$ & CA & Positive & $<20$ mSv/year & No \\
\hline Undeger et al., 1999, (60) & 30 (technicians) & $\begin{array}{l}30 \text { (nurses, } \\
\text { technicians, office } \\
\text { personnel) }\end{array}$ & Comet & Positive & $50 \mathrm{mSv} /$ year. & No \\
\hline Cardoso et al, 200I, (6I) & $\begin{array}{l}8 \text { (workers in X-rays, } \\
\text { radiotherapy and } \\
\text { nuclear medicine } \\
\text { sectors) }\end{array}$ & $\begin{array}{l}8 \text { (healthy } \\
\text { individuals) }\end{array}$ & $\begin{array}{l}\text { CA } \\
\text { MN } \\
\text { SCE }\end{array}$ & Positive & $63.2 \mathrm{mSv} / \mathrm{life}$ & No \\
\hline Maluf et al, 200I, (62) & 22 (hospital workers) & $\begin{array}{l}22 \text { (non-exposed } \\
\text { workers) }\end{array}$ & $\begin{array}{l}\text { MN } \\
\text { Comet }\end{array}$ & Positive & $0.2-121 . \mathrm{mSv}$ & No \\
\hline Maffei et al, 2002, (63) & $\begin{array}{l}37 \text { (physicians, } \\
\text { technicians) }\end{array}$ & $\begin{array}{l}37 \text { (non-exposed } \\
\text { workers }\end{array}$ & $M N$ & $\begin{array}{l}\text { Negative/ } \\
\text { Positive }\end{array}$ & $35 \mathrm{mSv} /$ life & No \\
\hline Bozkurt et al, 2003, (64) & 16 (nuclear medicine) & $\begin{array}{l}16 \text { (non-exposed } \\
\text { physicians) }\end{array}$ & SCE & Positive & $3.39 \mathrm{mSv} /$ year. & Yes \\
\hline $\begin{array}{l}\text { Garaj-Vrhovac and } \\
\text { Kopjar, 2003, (65) }\end{array}$ & $\begin{array}{l}50 \text { (physicians, } 25 \\
\text { technicians, } 10 \text { nurses) }\end{array}$ & $\begin{array}{l}50 \text { (healthy } \\
\text { students and office } \\
\text { employees) }\end{array}$ & Comet & Positive & 0-8.5 mSv/year. & No \\
\hline Maffei et al, 2004, (66) & $\begin{array}{l}34 \text { (physicians, } \\
\text { technicians) }\end{array}$ & $\begin{array}{l}35 \text { (non-exposed } \\
\text { workers) }\end{array}$ & CA & Positive & $\begin{array}{l}\text { I.8I-I4I.77 mSv/ } \\
\text { life. }\end{array}$ & Yes \\
\hline Zakeri et al., 2004, (67) & $\begin{array}{l}\text { 7I (cardiologists, } \\
\text { nurses and technicians) }\end{array}$ & $\begin{array}{l}36 \text { (healthy } \\
\text { individuals) }\end{array}$ & $\begin{array}{l}\mathrm{CA} \\
\mathrm{MN}\end{array}$ & Positive & $3.0 \mathrm{mSv} /$ year & No \\
\hline $\begin{array}{l}\text { Andreassi et al, 2004, } \\
\text { (67) }\end{array}$ & $\begin{array}{l}31 \text { interventional } \\
\text { cardiologists }\end{array}$ & $\begin{array}{l}31 \text { clinical } \\
\text { cardiologists }\end{array}$ & $\mathrm{MN}$ & Positive & $4 \mathrm{mSv} /$ year & No \\
\hline
\end{tabular}

SCE: sister-chromatid exchange; MN: Micronuclei; CA: Chromosomal aberrations;

may underestimate the real dose exposure if the badges are not properly worn. The potential combined effect of other genotoxic exposures would also induce DNA damage, enhancing the effect of radiation exposure [63]. Moreover, genetic susceptibility may account for the interindividual differences to radiation sensitivity. Such possible susceptibility may recognize sources of variability (genetic polymorphism) in people's DNA repair gene sequence [69]. However, it is interesting to underline that, in a group of radiologists, it has been documented an important parallelism between the decrease of the exposure to ionizing radiation in the hospitals and a reduction in the frequency of chromosome aberrations over the most recent decades [58] (Figure 4). This decrease was the result of an efficient protection policy among radiologists. Unfortunately, this is not the case for invasive cardiologists who need to know very well both the long-term risks and the doses involved in the large amount of examinations they prescribe and/or perform every day $[40,41]$.

As matter of fact, our results and a recent monitoring of personnel working in angiocardiography laboratories in Iranian Hospitals showed a high frequency of chromosome aberrations in cardiologists s and technicians compared to unexposed subjects $[68,69]$.

Taken together, these evidences highlight that the use of a biological dosimeter could complement the data 
mSv (mean dose/year)

a)

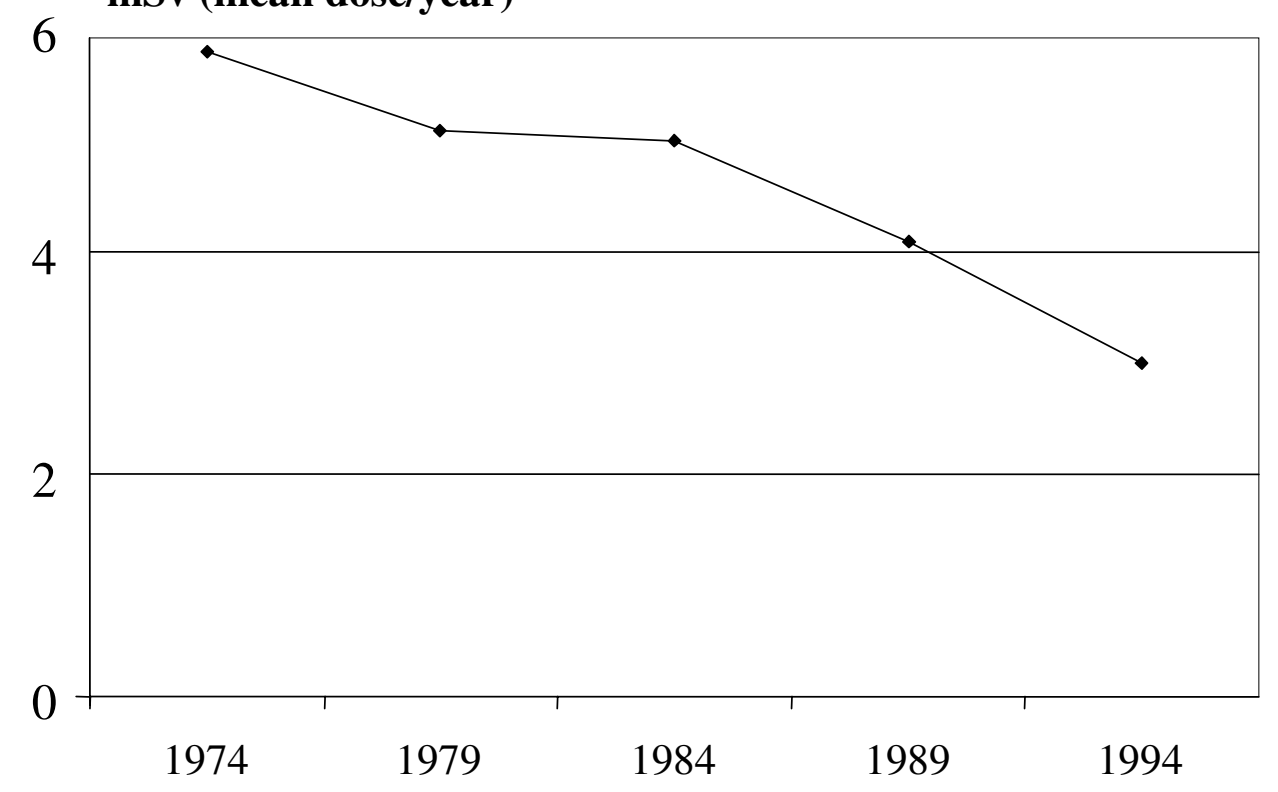

\% chromosomal aberrations

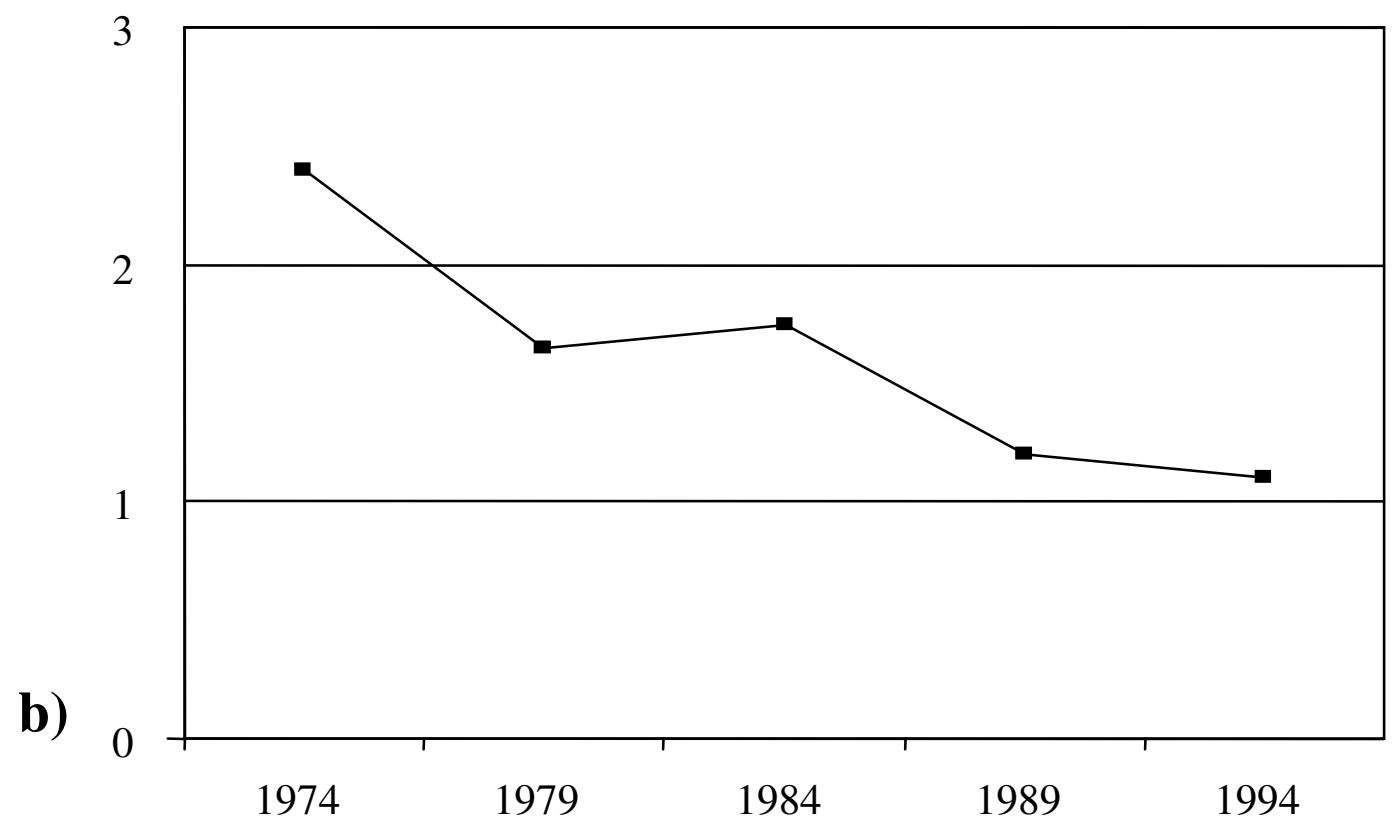

Figure 4

a) Decrease in exposure to ionizing radiation in hospital radiologists over the most recent decades and b) a similar time-related reduction in the frequency of chromosome-type aberrations (redrawn from ref. 58) 
obtained by physical dosimetry and reduce the uncertainties of low-dose radiation risk assessment [70]. The analysis of chromosome aberrations is the gold standard endpoint for radiation biological dosimetry. Limitations and strengths on biodosimetry have been fully discussed in the IAEA Report 405 [70]. A possible limitation is the response to high radiation dose $(>4 \mathrm{~Sv}$ ) where cell death and delays in progression through the cycle represents a pitfall for estimation of acute irradiation particularly when non-uniform or partial body irradiation have occurred.

Moreover, the method is laborious, time consuming and requires expert skills. Scoring of micronuclei has been proposed as an alternative to conventional chromosome aberrations analysis, being more sensitive and faster [71].
Although micronuclei method has been improved, interlaboratories discrepancies have emphasized the need for better standardization [53].

However, in many countries the application of cytogenetic dosimetry has yet medical-legal recognition, and it is complementary to physical dosimetry. On the other hand, the usefulness of biomarkers as early biological effects, with special concern for the prediction of cancer, has been recently emphasized [72]. Therefore, the application of biodosimetry- that measures true cellular injury resulting from that radiation- could greatly enhance health risk, identifying susceptible individuals and enhancing the possibility of preventive measures, especially in occupational settings with a high volume of radiological activities (Figure 5).
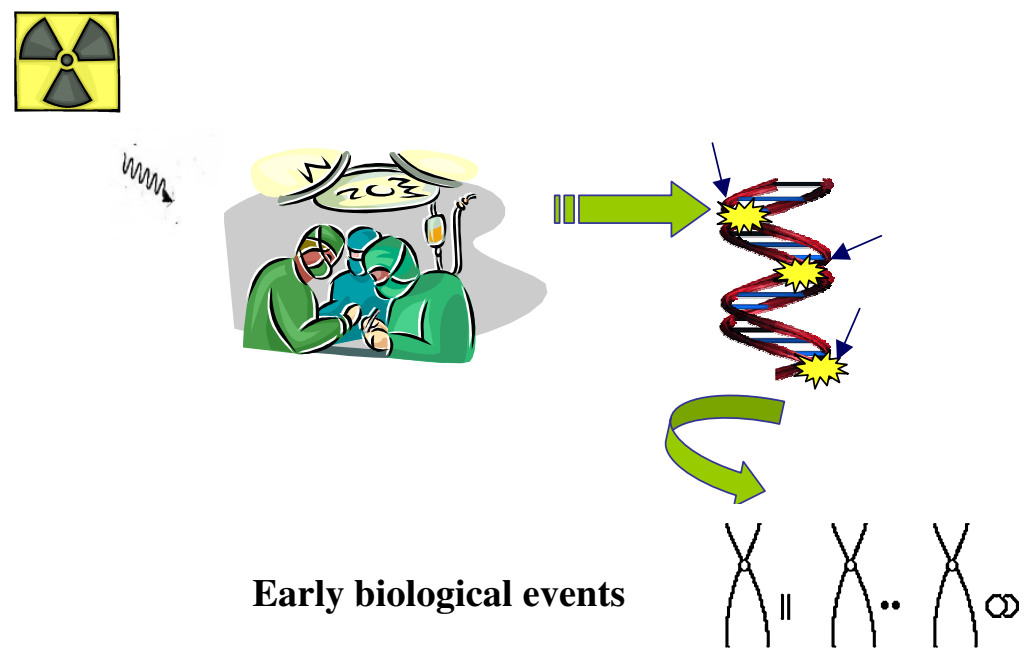

INDIVIDUAL RISK
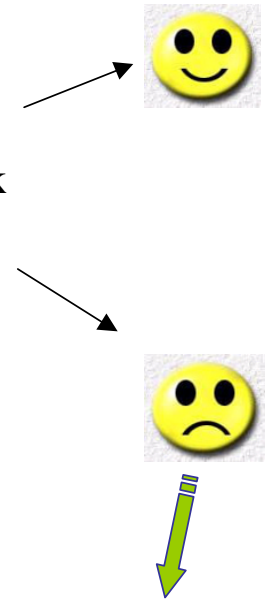

Clinical Disease

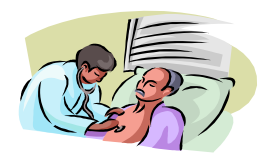

\section{Figure 5}

Illustration of potential use of biomarkers as early predictors of clinical disease. The evaluation of genetic effects such as chromosomal damage could be used to anticipate delayed health outcomes, providing a greater potential for preventive measures. 


\section{Conclusion}

Occupational exposure can occur in cardiological procedures which employ ultrasound and ionizing radiation. Today, there are no consistent adverse biological effects on operators caused by exposures to ultrasound. However, it is clearly necessary to continually monitor both the potential risks and safety of ultrasound exposure. In contrast, exposure to ionizing radiation may result in adverse health effect on both cardiologists directly and on their progeny. Although the current risk estimates are clouded by approximations and extrapolations, most data from cytogenetic studies have reported an enhanced DNA damage in hospital workers exposed to chronic low doses of ionizing radiation. The occupational dose of interventional cardiologists, and electrophysiologists tend to be higher compared to other medical specialists as a result of the recent increasing use of interventional techniques. On the other hand, physicians are dramatically unaware of dose, long-term risks and populations health impact caused by the use of medical ionizing radiation. Thus, a major awareness appears to be crucial in order to improve both one's knowledge on the appropriateness of protective tools and also in trying to reduce the number of unnecessary procedures. The use of a biological dosimeter could be a reliable tool for risk quantification on an individual basis.

\section{References}

I. Higgins CB: Cardiac imaging. Radiology 2000, 21 7:4-I0.

2. International Commission on Radiological Protection (ICRP): Radiation and your patient: a guide for medical practitioners. A web module produced by Committee 3 of the ICRP. Oxford, UK: Pergamon Press; 2001.

3. European Commission. Radiation protection II8: Referral guidelines for imaging. [http://europa.eu.int/comm/environment/rad prot/II8/rp-II8-en.pdf]. (accessed 23 July 2004)

4. Council Directive 97/43/Euratom of 30 June 1997 on health protection of individuals against the dangers of ionizing radiation in relation to medical exposure, and repealing Directive 84/466/Euratom. Official Journal of the European Communities L 180:0022-0027. 09/07/1997

5. Picano E: Sustainability of medical imaging. Education and Debate. BMJ 2004, 328:578-580.

6. Shiralkar S, Rennie A, Snow M, Galland RB, Lewis MH, Gower-Thomas K: Doctors' knowledge of radiation exposure: questionnaire study. $B M]$ 2003, 327:37I-372.

7. Finestone A, Schlesinger T, Amir H, Richter E, Milgrom C: Do physicians correctly estimate radiation risks from medical imaging? Arch Environ Health 2003, 58:59-6I.

8. Lee Cl, Haims AH, Monico EP, Brink JA, Forman HP: Diagnostic CT scans: assessment of patient, physician, and radiologist awareness of radiation dose and possible risks. Radiology 2004, 231:393-398.

9. Correia MJ, Hellies A, Andreassi MG, Ghelarducci B, Picano E: Lack of Radiological Awareness in a Tertiary Care Cardiological Centre. Int J Cardiol 2005 in press.

10. Nyborg WL: Biological effects of ultrasound: development of safety guidelines. Part II: general review. Ultrasound Med Biol 2001, 27:30I-333.

II. American Institute of Ultrasound in Medicine (Bioeffects Committee): Bioeffects considerations for the safety of diagnostic ultrasound. American Institute of Ultrasound in Medicine. J Ultrasound Med I988, 7:SI-38.

12. Liebeskind D, Bases R, Elequin F, Neubort S, Leifer R, Goldberg R, Koenigsberg M: Diagnostic ultrasound: effects on the DNA and growth patterns of animal cells. Radiology 1979, 13 I:177-184.
13. Fuciarelli AF, Sisk EC, Thomas RM, Miller DL: Induction of base damage in DNA solutions by ultrasonic cavitation. Free Radic Biol Me 1995, I 8:231-238.

14. Miller MW, Wolff S, Filly R, Cox C, Carstensen EL: Absence of an effect of diagnostic ultrasound on sister-chromatid exchange induction in human lymphocytes in vitro. Mutat Res 1983, I 20:26I-268.

15. Stella M, Trevisan L, Montaldi A, Zaccaria G, Rossi G, Bianchi V, Levis AG: Related Induction of sister-chromatid exchanges in human lymphocytes exposed in vitro and in vivo to therapeutic ultrasound. Mutat Res 1984, 138:75-78.

16. Barnett SB, Barnstable SM, Kossoff G: Sister chromatid exchange frequency in human lymphocytes after long duration exposure to pulsed ultrasound. J Ultrasound Med 1987, 6:637-642.

17. Carrera P, Orsini S, Terzoli G, Brambati B, Simoni G: Sister chromatid exchanges in first-trimester chorionic villi after in vivo and in vitro exposure to diagnostic ultrasound. Prenat Diagn 1990, 10:141-158.

18. Miller MW, Azadniv M, Cox C, Miller WM: Lack of induced increase in sister chromatid exchanges in human lymphocytes exposed to in vivo therapeutic ultrasound. Ultrasound Med Biol 1991, 17:8I-83.

19. Martin AO, Madsen EL, Dyer AR, White L, Bouck NP, Sabbagha RE, Hermanoff M, Chen JM, Ludtke LJ: Sister chromatid exchange analysis of human cells exposed to diagnostic levels of ultrasound. J Ultrasound Med 199I, 10:665-670.

20. Sahin O, Donmez-Altuntas H, Hizmetli S, Hamurcu Z, Imamoglu N: Investigation of genotoxic effect of ultrasound in cases receiving therapeutic ultrasound by using micronucleus method. Ultrasound Med Biol 2004, 30:545-548.

21. Nyborg WL: Human Exposure to ultrasound. Appl Occup Environ Hygn 1996, I I:25I-254.

22. Garaj-Vrhovac V, Kopjar N: Cytogenetic monitoring of cardiology unit hospital workers exposed to Doppler ultrasound. J Appl Toxicol 2000, 20:259-264.

23. Beir V: Health effects of exposure to low levels of ionizing radiation. In Prepared by the Committee on the Biological Effects of lonizing Radiation, National Research Council, Washington, DC National Academy Press; 1990.

24. Report of the United States Nations Scientific Committee on the Effects of Atomic Radiation to the General Assembly: Annex G: Biological effects at low radiation doses. USCEAR $200 \mathrm{I}$.

25. Hall Ej: Radiobiology for the Radiologist. 5th edition. Lippincott Williams \& Wilkins, Philadelphia, PA; 2000.

26. International Commission on Radiological Protection. ICRP Publication 59: The biological basis for dose limitation in the skin. Annals of the ICRP 1991:22.

27. National Radiological Protection Board: Risk from deterministic effects of ionizing radiation. In Documents of the National Radiological Protection Board 7 London: HMSO; 1996.

28. Brenner DJ, Doll R, Goodhead DT, Hall EJ, Land CE, Little JB, Lubin $J H$, Preston DL, Preston RJ, Puskin JS, Ron E, Sachs RK, Samet JM, Setlow RB, Zaider M: Cancer risks attributable to low doses of ionizing radiation: assessing what we really know. Proc Natl Acad Sci USA 2003, 100:1376I-13766.

29. National Council on Radiation Protection and Measurements: Evaluation of the Linear-Nonthreshold Dose-Response Model for lonizing Radiation. NCRP, Bethesda 200I. Report No.136

30. Dubrova YE: Long-term genetic effects of radiation exposure. Mutat Res 2003, 544:433-439.

31. Gardner MJ, Snee MP, Hall AJ, Powell CA, Downes S, Terrell JD: Results of case-control study of leukaemia and lymphoma among young people near Sellafield nuclear plant in West Cumbria. BM] 1990, 300:423-429.

32. Hama $Y$, Uematsu M, Sakurai $Y$, Kusano S: Sex ratio in the offspring of male radiologists. Acad Radiol 200I, 8:42I-424.

33. Dubrova YE, Grant G, Chumak AA, Stezhka VA, Karakasian AN: Elevated minisatellite mutation rate in the post-chernobyl families from ukraine. Am J Hum Genet 2002, 7 I:801-809.

34. Kiuru A, Auvinen A, Luokkamaki M, Makkonen K, Veidebaum T, Tekkel M, Rahu M, Hakulinen T, Servomaa K, Rytomaa T, Mustonen R: Hereditary minisatellite mutations among the offspring of Estonian Chernobyl cleanup workers. Radiat Res 2003, 159:65I-655.

35. Slebos RJ, Little RE, Umbach DM, Antipkin Y, Zadaorozhnaja TD, Mendel NA, Sommer CA, Conway K, Parrish E, Gulino S, Taylor JA: 
Mini-and microsatellite mutations in children from Chernobyl accident cleanup workers. Mutat Res 2004, 559:|43-I5I.

36. Regulla D, Griebel J, Nosske D, Bauer B, Brix G: Acquisition and assessment of patient exposure in diagnostic radiology and nuclear medicine. Z Med Phys 2003, 13:127-135.

37. Renaud L: $\mathbf{A} \mathbf{5}$-year follow up of the radiation exposure to inroom personnel during cardiac catheterization. Health Phys 1992, 62:10-15.

38. Vano E, Gonzalez L, Beneytez F, Moreno F: Lens injuries induced by occupational exposure in non-optimised interventional radiology laboratories. $\mathrm{Br} J$ Radiol 1998, 7 I:728-733.

39. McKetty MH: Study of radiation doses to personnel in a cardiac catheterisation laboratory. Health Phys 1996, 70:563-567.

40. Finkelstein MM: Is brain cancer an occupational disease of cardiologists? Can J Cardiol 1998, 14:1385-1388.

41. Vano E: Radiation exposure to cardiologists: how it could be reduced. Heart 2003, 89: I 123-I I 24.

42. Delichas M, Psarrakos K, Molyvda-Athanassopoulou E, Giannoglou G, Sioundas A, Hatziioannou K, Papanastassiou E: Radiation exposure to cardiologists performing interventional cardiology procedures. Eur J Radiol 2003, 48:268-273.

43. Kuon E, Birkel J, Schmitt M, Dahm JB: Radiation exposure benefit of a lead cap in invasive cardiology. Heart 2003, 89: 1205-1216.

44. Berrington De Gonzalez A, Darby S: Risk of cancer from diagnostic X-rays: estimates for the UK and 14 other countries. Lancet 2004, 363:345-35I.

45. Picano E: Risk of Cancer from diagnostic X-rays: impressive but underestimated. Lancet 2004, 363:1909-1910.

46. Yoshinaga S, Mabuchi K, Sigurdson AJ, Doody MM, Ron E: Cancer risks among radiologists and radiologic technologists: review of epidemiologic studies. Radiology 2004, 233:3I3-32I.

47. Gofman JW: Radiation from medical procedures in the pathogenesis of cancer and ischemic heart disease: dose-response studies with physicians per 100,000 population, San Francisco. Committee for Nuclear Responsibility Books, Available at UCSF Med. Library. The Exec Summary online 1999 [http://www.ratical.org/ radiation/CNR/RMP/].

48. Preston DL, Shimizu Y, Pierce DA, Suyama A, Mabuchi K: Studies of mortality of atomic bomb survivors. Report 13: Solid cancer and noncancer disease mortality: 1950-1997. Radiat Res 2003, 160:38I-407.

49. Bonassi S: Combining environmental exposure and genetic effect measurements in health outcome assessment. Mutat Res 1999, 428: 177-185.

50. Pavanello S, Clonfero E: Biological indicators of genotoxic risk and metabolic polymorphisms. Mutat Res 2000, 463:285-308.

51. Hagmar L, Bonassi S, Stromberg U, Brogger A, Knudsen LS, Norppa $\mathrm{H}$, Reuterwall C, European Study Group on Cytogenetic Biomarkers and Health: Chromosomal aberrations in lymphocytes predict human cancer: a report from the European Study Group on Cytogenetic Biomarkers and Health (ESCH). Cancer Res 1998, 58:4||7-4|2|.

52. Hagmar L, Stromberg U, Bonassi S, Hansteen IL, Knudsen LE, Lindholm C, Norppa H: Impact of types of lymphocyte chromosomal aberrations on human cancer risk: results from Nordic and Italian cohorts. Cancer Res 2004, 64:2258-2263.

53. Fenech $M$ : Biomarkers of genetic damage for cancer epidemiology. Toxicology 2002, |8|-1 82:4||-6.

54. Bigatti P, Lamberti L, Ardito G, Armellino F: Cytogenetic monitoring of hospital workers exposed to low-level ionizing radiation. Mutat Res 1988, 204:343-347.

55. Barquinero JF, Barrios L, Caballin MR, Miro R, Ribas M, Subias A Egozcue J: Cytogenetic analysis of lymphocytes from hospital workers occupationally exposed to low levels of ionizing radiation. Mutat Res 1993, 286:275-279.

56. Paz-y-Mino C, Leone PE, Chavez M, Bustamante G, Cordova A, Gutierrez S, Penaherrera MS, Sanchez ME: Follow up study of chromosome aberrations in lymphocytes in hospital workers occupationally exposed to low levels of ionizing radiation. Mutat Res 1995, 335:245-251.

57. Vera GV, Aleksandra F, Dragan K, Andrija H: Assessment of genome damage in occupational exposure to ionizing radiation and ultrasound. Mutat Res 1997, 395: 01 I-105.

58. Bonassi S, Forni A, Bigatti P, Canevarollo N, De Ferrari M, Lando C, Padovani P, Bevegni M, Stella M, Vecchio D, Puntoni R: Chromosome aberrations in hospital workers: evidence from surveil- lance studies in Italy (1963-1993). Am J Ind Med 1997, 3I:353-360.

59. Rozgaj R, Kasuba V, Sentija K, Prlic I: Radiation-induced chromosomal aberrations and haematological alterations in hospital workers. Occup Med 1999, 49:353-360.

60. Undeger U, Zorlu AF, Basaran N: Use of the alkaline comet assay to monitor DNA damage in technicians exposed to low-dose radiation. J Occup Environ Med 1999, 41:693-698.

61. Cardoso RS, Takahashi-Hyodo S, Peitl P, Ghilardi-Neto T, SakamotoHojo ET: Evaluation of chromosomal aberrations, micronuclei, and sister chromatid exchanges in hospital workers chronically exposed to ionizing radiation. Teratog Carcinog Mutagen 200I, 2 I:43I-439.

62. Maluf SW, Passos DF, Bacelar A, Speit G, Erdtmann B: Assessment of DNA damage in lymphocytes of workers exposed to $X$ radiation using the micronucleus test and the comet assay. Environ Mol Mutagen 200I, 38:3II-3I5.

63. Maffei F, Angelini S, Forti GC, Lodi V, Violante FS, Mattioli S, Hrelia P. Micronuclei frequencies in hospital workers occupationally exposed to low levels of ionizing radiation: influence of smoking status and other factors. Mutagenesis 2002, I 7:405-409.

64. Bozkurt G, Yuksel M, Karabogaz G, Sut N, Savran FO, Palanduz S, Yigitbasi ON, Algunes C: Sister chromatid exchange in lymphocytes of nuclear medicine physicians. Mutat Res 2003, 535:205-2/3.

65. Graj-Vrhovac Vera, Kopjar N: The alkaline Comet assay as biomarker in assessment of DNA damage in medical personnel occupationally exposed to ionizing radiation. Mutagenesis 2003, 18:265-27I.

66. Maffei F, Angelini S, Forti GC, Violante FS, Lodi V, Mattioli S, Hrelia P: Spectrum of chromosomal aberrations in peripheral lymphocytes of hospital workers occupationally exposed to low doses of ionizing radiation. Mutat Res 2004, 547:91-99.

67. Zakeri F, Assaei RG: Cytogenetic monitoring of personnel working in angiocardiography laboratories in Iran hospitals. Mutat Res 2004, 562: I-9.

68. Andreassi MG, Joksic G, Manfredi S, Alavantic D, Cioppa A, Botto N, Hellies A, Ostojic M, Rubino P, Picano E: omatic DNA damage in interventional cardiologists. Eur Heart J 2004, 25:570. (abstract)

69. Aka P, Mateuca R, Buchet JP, Thierens H, Kirsch-Volders M: Are genetic polymorphisms in OGGI, XRCCI and XRCC3 genes predictive for the DNA strand break repair phenotype and genotoxicity in workers exposed to low dose ionising radiations? Mutat Res 2004, 556:169-18I.

70. International Atomic Energy Agency (IAEA): Cytogenetic analysis for Radiation Dose Assessment. Technical Report 200I, 405:.

7I. Fenech M, Gledhill BL, Mauro F, Ed: Optimisation of micronucleus assays for biological dosimetry. in New Horizons in Biological Dosimetry (Wiley, New York) 1981:373-376.

72. Bonassi S, Au WW: Biomarkers in molecular epidemiology studies for health risk prediction. Mutat Res 2002, 5 I I:73-86.

Publish with Bio Med Central and every scientist can read your work free of charge

"BioMed Central will be the most significant development for disseminating the results of biomedical research in our lifetime. "

Sir Paul Nurse, Cancer Research UK

Your research papers will be:

- available free of charge to the entire biomedical community

- peer reviewed and published immediately upon acceptance

- cited in PubMed and archived on PubMed Central

- yours - you keep the copyright 